responsive to changes in blood glucose, and evidence has been provided that this action is probably mediated by the hypothalamus, constituting a physiological "feedback" mechanism.

We thank the physicians and surgeons of St. Vincent's Hospital for referring patients under their care to this study, and Mr. F. B. Griffiths and Miss S. Whitington for performing blood glucose estimations.

\section{REFERENCES}

Anand, B. K, Chhina, G. S, and Singh, B. (1952). Science, 138, 597. Byrnes, D. J., Young, J., and Lazarus, L. (1969) Proceedings of the Australian Society for Medical Research, 2, 282

Dragstedt, L. R. (1965). Lancet, 1, 816.

Edkins, J. S. (1905). Proceedings of the Royal Society Series B, 76, 376 Emås, S., and Fyrö, B. (1964). Gastroenterology, 46, 1.
Gregory, R. A., Grossman, M. I., Tracy, H. J., and Bcntley, P. H. (1967). Lancet, 2, 543.

Hollander, F. (1948). Gastroenterology, 11, 419.

Kraegen, E. W. (1969). Ph.D. Thesis, N.S.W. University Australia.

Levin, E., Kirsner, J. B., Palmer, W. L., and Butler, C. (1948). Gastroenterology, io, 952 .

Littman, A. (1962). Gastroenterology, 43, 166

McGuigan, J. E., and Trudeau, W. L. (1968). New England fournal of Medicine, 278, 1308.

Odell, W. D., Charters, A. C., Davidson, W. D., and Thompson, J. C. (1968). Fournal of Clinical Endocrinology and Metabolism, 28, 1840.

Sun, D. C. H., Shay, H., and Ciminera, J. L. (1965). Fournal of the American Medical Association, 158, 713 .

Woodward, E. R., Hayes, P. V., Tovee, E. B., and Dragstedt, L. R. (1949) Archives of Surgery, 59, 1191.

Young, J. D., Lazarus, L., Chisholm, D. J., and Atkinson, F. F. V. (1969a). Fournal of Nuclear Medicine. 10, 743.

Young, J. D., Byrnes, D. J., Chisholm, D. J., Griffiths, F. B., and Lazarus, L. (1969b). Fournal of Nuclear Medicine, 10, 746.

Zollinger, R. M., and Ellison, E. H. (1955). Annals of Surgery, 142, 709.

\title{
Survey of Workers Exposed to Dusts Containing Derivatives of Bacillus Subtilis
}

\author{
M. GREENBERG ${ }^{*}$ M.B., M.R.C.P. ; JUDITH F. MILNE, $†$ M.B., M.R.C.P. ; A. WATT, ${ }^{*}$ M.B., D.P.H., D.I.H.
}

\begin{abstract}
ummary: In a survey of 121 workers exposed to dusts containing derivatives of Bacillus subtilis, mainly proteolytic enzymes, skin tests showed evidence of sentiztaion was higher among "atopic" subjects-16 out of tization was higher among "atopic" subjects-16 out of $25(64 \%)$-than among "non-atopic" subjects-32 out of $96(33 \%)$. Reduced ventilatory capacity was found in $44 \%$ of sensitized workers compared with $14 \%$ of those not sensitized.
\end{abstract}

\section{Introduction}

The introduction of washing powders containing derivatives of Bacillus subtilis-mainly proteolytic enzymes-has been associated with a health hazard to workers involved in their manufacture. Previous investigators have shown that these materials are allergenic and on inhalation can sensitize exposed subjects, some of whom develop respiratory symptoms (Flindt, 1969; Pepys et al., 1969). The present study was designed to survey all the workers exposed to such enzyme dusts at one detergent factory. Assessments were made by questionary, spirometry, and skin tests, with serological tests in selected subjects.

Early in June 1967 B. subtilis derivative was introduced into a washing-powder product, following which five workers complained of respiratory symptoms. Changes in plant design were made, and it was thought that the hazard had been eradicated as no further complaints were recorded for over six months. The survey was carried out, with the co-operation of management and workers, to test the effectiveness of the engineering measures.

The $B$. subtilis derivative concentrate in impervious $50-\mathrm{kg}$. paper sacks was taken from store as required and unloaded into metal bins in a room used exclusively by one man provided with air-line helmet and protective clothing. After use the room was hosed down. The bins were transported to an outside cabinet, where they were tipped into a chute from which the material was transported mechanically to the top of \footnotetext{
* H.M. Factory Inspectorate (Medical Branch), 1-13 Chepstow Place,

$T$ Lecturer, Department of Clinical Immunology, Institute of Diseases of the Chest, London S.W.3.
}

the mixing building. Packing was by an automatic machine equipped with exhaust ventilation situated in a room with tiled walls and floor which were regularly washed down.

The process was an intermittent one, so that during 1968, for example, a total of only 41 days had been spent using $B$. subtilis derivative in manufacture. The departmental labour force consisted of 46 women employed on two shifts and 65 men working three shifts. Others considered to be at risk were supervisors and maintenance men. The intensity and duration of exposure varied considerably within the group and could not be documented adequately in retrospect. A total of 121 workers were fully examined in May 1969. One worker was unable to complete the investigation so was omitted from the analysis. Eight who were unavailable in May were examined in September 1969, and their results are considered separately. It is thought that very few workers were missed on both occasions.

\section{Subjects and Methods}

The survey team consisted of investigators trained and well practised in the techniques of assessment used. Each of the 121 workers examined was seen on a single occasion during his working hours, so that assessments were made at various times of day and night.

Questionary.-The M.R.C. Questionary on Respiratory Symptoms, 1960, was used, with supplementary questions concerning complaints noted in previous studies of workers handling enzyme powders. The complaints included nasal symptoms (stuffiness or running of the nose, sneezing attacks, nose bleeding), chest symptoms (breathlessness, cough, chest pain), and general symptoms (shivering attacks, faintness, malaise).

Spirometry.-Measurements of forced expiratory volume in one second (F.E.V.1) and forced vital capacity (F.V.C.) were made with the McDermott dry spirometer, the mean of three technically satisfactory recordings being taken, after twc practice attempts.

Skin tests were carried out by the prick technique; beforf testing, the skin was rinsed with water to remove any materials the worker had been handling. Weal sizes were recorded 15 minutes after testing. A weal of $1 \mathrm{~mm}$. diameter or greater 
was regarded as a positive reaction, provided that there was no reaction to the control solution. A selection of common allergens was tested and the reactions to these extracts were used as the criteria for classifying subjects as "atopic" or "nonatopic": control solution, grass pollen, Cladosporium herbarum and Aspergillus fumigatus (Bencard Limited); cat skin, dog skin, horse skin (Dome Limited); Dermatophagoides farinae (culinae), related to D. Pteronyssinus the "house dust mite" (Pepys et al., 1969). Extracts of commercial enzyme dusts (Alcalase and Maxatase) and a crystalline proteinase derived from B. subtilis (Koch-Light Limited) were prepared as described by Pepys et al. (1969). They were dissolved in Coca's solution with $50 \%$ glycerol to prevent drying, and each was tested at three concentrations: $0.1,1$, and $10 \mathrm{mg} . / \mathrm{ml}$. In addition samples of all three extracts were heated to $100^{\circ} \mathrm{C}$. for 10 minutes (which destroys its capacity to give precipitation reactions), and heated extracts were tested at $10 \mathrm{mg} . / \mathrm{ml}$.

Serological tests for precipitating antibody were carried out by the agar gel double diffusion method at the Department of Clinical Immunology of the Institute of Diseases of the Chest (Pepys et al., 1969).

\section{Results}

Questionary.-A leading question oncerning chronic bronchitis produced only two positive answers, and a further three workers admitted to bronchial asthma following a leading question. Analysis identified nine workers as having a chronic condition characterized by increased sputum production and episodes of chest illness. One had the chronic bronchitis syndrome only (College of General Practitioners, 1961); seven had the sputum/chest illness syndrome only (Lloyd Davies, 1970)*; one worker conformed to both syndromes. Tables I and II relate complaints recorded in the questionary to other results, and Table III gives details of smoking patterns.

\begin{tabular}{|c|c|c|c|c|c|c|c|}
\hline & & & & & & $\begin{array}{l}\text { Enzyme } \\
\text { Positive }\end{array}$ & $\begin{array}{l}\text { Enzyme } \\
\text { Negative }\end{array}$ \\
\hline Total & .. & $\ldots$ & .. & $\ldots$ & . & 48 & 73 \\
\hline $\begin{array}{l}\text { No respiratc } \\
\text { Cough } \\
\text { Dyspnoea } \\
\text { Chest pain } \\
\text { Nose/eye ir }\end{array}$ & \begin{tabular}{cr}
\multicolumn{3}{c}{ ory compl } \\
$\ldots$ & $\ldots$ \\
$\ldots$ & $\cdots$ \\
\hdashline ritation.
\end{tabular} & $\begin{array}{l}\text { ts } \\
\cdots \\
\cdots \\
\cdots\end{array}$ & $\begin{array}{l}\cdots \\
\cdots \\
\cdots \\
\cdots\end{array}$ & $\begin{array}{l}\cdots \\
\cdots \\
\cdots \\
\cdots\end{array}$ & $\begin{array}{l}. \\
\cdots \\
\cdots \\
\therefore\end{array}$ & $\begin{array}{r}11(23 \%) \\
8(17 \%) \\
12(25 \%) \\
5(10 \%) \\
29(60 \%)\end{array}$ & $\begin{array}{r}21(29 \%) \\
9(12 \%) \\
14(19 \%) \\
10(14 \%) \\
48(66 \%)\end{array}$ \\
\hline
\end{tabular}

TABLE II.-Ventilatory Capacity and Complaints

\begin{tabular}{|c|c|c|c|c|c|c|}
\hline & & & & & $\mid$\begin{tabular}{|c} 
F.E.V.1/F.V.C. \\
Below 70\%
\end{tabular} & $\begin{array}{l}\text { F.E.V., } / \text { F.V.C.C. } \\
\text { Above } 70 \%\end{array}$ \\
\hline Total subjects & .. & .. & .. & .. & 31 & 90 \\
\hline \multicolumn{3}{|c|}{ 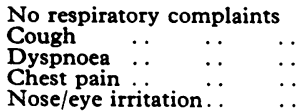 } & 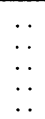 & $\begin{array}{l}\cdots \\
\cdots \\
\because \\
\because\end{array}$ & $\begin{array}{r}5(17 \%) \\
6(20 \%) \\
13(43 \% \%) \\
6(20 \%) \\
17(57 \%)\end{array}$ & $\begin{array}{r}27(30 \%) \\
13(14 \%) \\
15(17 \%) \\
9(10 \%) \\
60(66 \%)\end{array}$ \\
\hline
\end{tabular}

* The sputum/chest illness syndrome (Lloyd Davies, 1970). Subjects giving the answer "yes" to the following questions of the M.R.C. questionary:

10. Do you bring up any phlegm (like this) on most days or nights for as much as 3 months each year? "Like this" refers to the preceding question: 6. Do you usually bring up any phlegm from your chest first thing in the morning in the winter? 8 . Do you usually bring up any phlegm from your chest during the day or at night in the winter?)

21. During the past 3 years have you had any chest illness which has kept you from your usual activities for as much as a week?
TABLE III.-Enzyme Sensitization, Smoking Habits, and Ventilatory

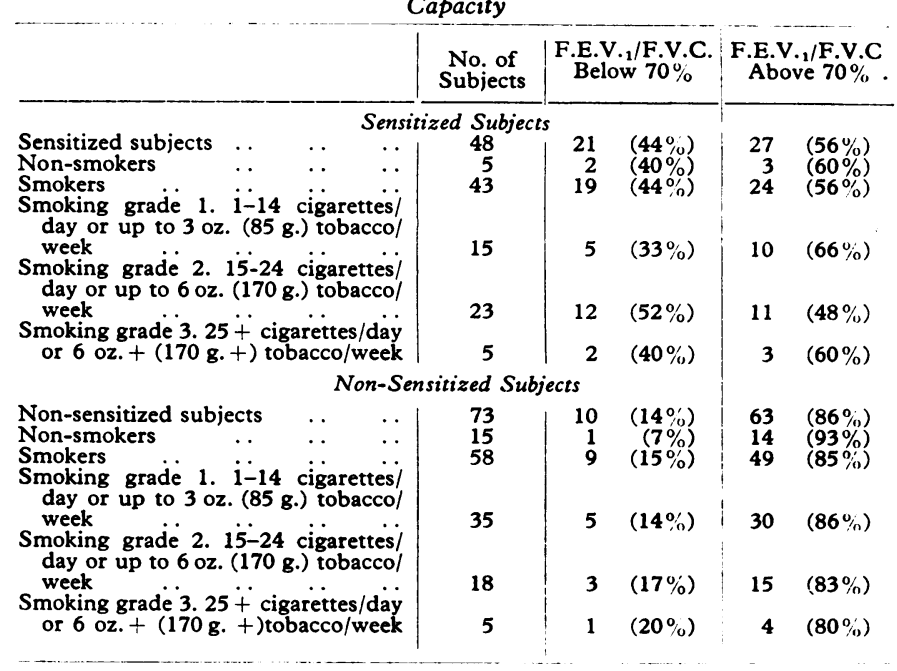

Spirometric Measurements.-The observed F.E.V.1/F.V.C. ratio was calculated for each individual and the results are summarized in the Chart. Subjects with an F.E.V.1/F.V.C. ratio below $70 \%$ were arbitrarily defined as having reduced ventilatory capacity. These results are related to atopic status and $B$. subtilis sensitization in Table IV. It can be seen that reduced ventilatory capacity was found in 21 out of $48(44 \%)$ sensitized subjects compared with 10 out of 73 (14\%) nonsensitized subjects.

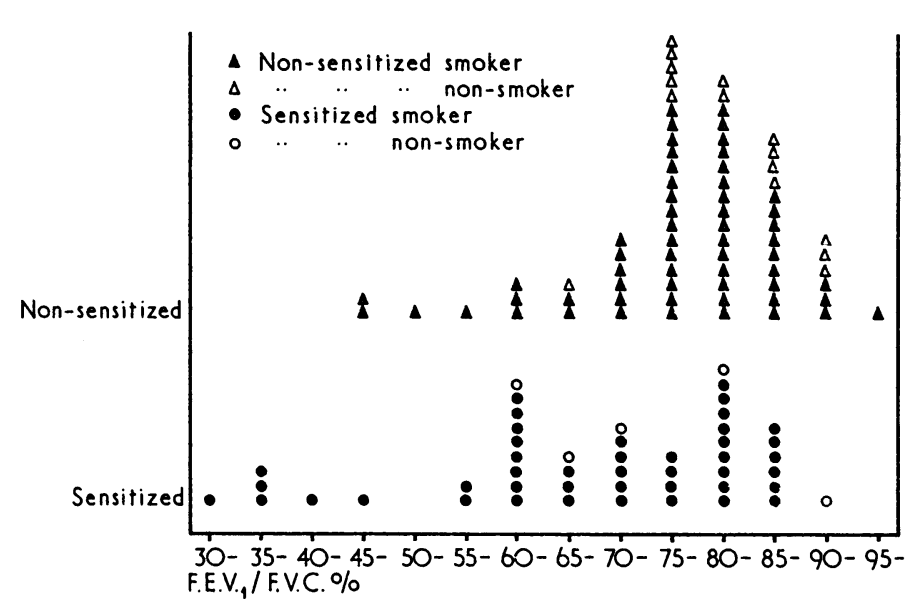

Distribution of ventilatory capacity, smoking habits, and enzyme sensitization

TABLE IV.-Enzyme Sensitization, Atopic Status, and Ventilatory Capacity

\begin{tabular}{|c|c|c|c|c|c|c|}
\hline & Total & $\begin{array}{r}\text { S } \\
\text { with } \\
\text { F.E. }\end{array}$ & $\begin{array}{l}\text { o. of } \\
\text { bjects } \\
\text { Observed } \\
{ }_{1}^{1 / F} \text {.V.C. } \\
70 \%\end{array}$ & $\begin{array}{l}\text { Mean } \\
\text { F.E.V.1 } \\
\text { (litres) }\end{array}$ & $\begin{array}{l}\text { Mean } \\
\text { F.V.C. } \\
\text { (litres) }\end{array}$ & $\begin{array}{c}\text { Mean } \\
\text { F.E.V. }{ }^{1 /} \\
\text { F.V.C. }\end{array}$ \\
\hline $\begin{array}{lll}\text { Atopic } & . & \ldots \\
\text { Non-atopic } & . & \ldots\end{array}$ & $\begin{array}{l}25 \\
96\end{array}$ & $\begin{array}{r}9 \\
22\end{array}$ & $\begin{array}{l}(36 \%) \\
(22 \%)\end{array}$ & $\begin{array}{l}2 \cdot 85 \\
2 \cdot 89\end{array}$ & $\begin{array}{l}3.93 \\
3.81\end{array}$ & $\begin{array}{l}73 \% \\
76 \%\end{array}$ \\
\hline $\begin{array}{l}\text { Total enzyme positive } \\
\text { Total enzyme negative }\end{array}$ & $\begin{array}{l}48 \\
73\end{array}$ & $\begin{array}{l}21 \\
10\end{array}$ & $\begin{array}{l}(44 \%) \\
(14 \%)\end{array}$ & $\begin{array}{l}2 \cdot 64 \\
3.04\end{array}$ & $\begin{array}{l}3.80 \\
3.86\end{array}$ & $\begin{array}{l}70 \% \\
79 \%\end{array}$ \\
\hline $\begin{array}{l}\text { Atopic enzyme } \\
\text { positive } . . \\
\text { Atopic enzyme } \\
\text { negative } \quad .\end{array}$ & $\begin{array}{r}16 \\
9\end{array}$ & 8 & $\begin{array}{l}(50 \%) \\
(11 \%)\end{array}$ & $\begin{array}{l}2 \cdot 46 \\
3 \cdot 55\end{array}$ & $\begin{array}{l}3.66 \\
4.63\end{array}$ & $\begin{array}{l}67 \% \\
77 \%\end{array}$ \\
\hline $\begin{array}{c}\text { Non-atopic enzyme } \\
\text { positive } . . \\
\text { Non-atopic enzyme } \\
\text { negative } \ldots\end{array}$ & $\begin{array}{l}32 \\
64\end{array}$ & 13 & $\begin{array}{l}(41 \%) \\
(14 \%)\end{array}$ & $2 \cdot 74$ & $3 \cdot 87$ & $71 \%$ \\
\hline
\end{tabular}


Skin Tests.-On skin (prick) testing, 25 workers showed one or more reactions to common allergens and are regarded as "atopic" subjects; the remaining 96 subjects are regarded as "non-atopic." Tests with the enzyme extracts produced immediate reactions in 48 workers, $40 \%$ of the total population (Table V). No late skin reactions were observed, nor any systemic reactions. Positive reactions to enzyme extracts occurred in $64 \%$ of atopic and $33 \%$ of non-atopic subjects (Table VI). The number of subjects reacting to each skin test extract and the average weal diameters recorded are shown in Tables VII and VIII. The pattern of reactions to common allergens is as would be expected in this country, with reactions occurring most frequently to grass pollen and the "house-dust mite." Reactions to the enzyme extracts become weaker with decreasing concentrations, but some subjects react to even the weakest extracts, indicating their high degree of sensitivity. The number and size of reactions to the Alcalase extract and the purified proteinase are very similar, but Maxatase extract appears to be slightly less potent. The heated extracts reacted in a small number of subjects only; in each case there were strong reactions to the unheated enzymes.

\begin{tabular}{|c|c|c|c|c|}
\hline \multirow{2}{*}{ No. Tested } & \multicolumn{2}{|c|}{ Common Allergens } & \multicolumn{2}{|c|}{ Enzyme Extracts } \\
\hline & $\begin{array}{l}\text { Positive } \\
\text { "Atopic" }\end{array}$ & $\begin{array}{c}\text { Negative } \\
\text { "Non-atopic" }\end{array}$ & Positive & Negative \\
\hline 121 & $25 \quad(21 \%)$ & 96 & $48 \quad(40 \%)$ & 73 \\
\hline
\end{tabular}

\begin{tabular}{|c|c|c|c|c|c|c|c|c|c|}
\hline & & \multirow{2}{*}{$\begin{array}{l}\text { Non-atopic } \\
\text { Subjects }\end{array}$} & \multirow{2}{*}{\multicolumn{2}{|c|}{$\begin{array}{l}\text { Atopic } \\
\text { Subjects }\end{array}$}} & \multicolumn{5}{|c|}{$\begin{array}{l}\text { No. of Positive Reactions } \\
\text { to Common Allergens }\end{array}$} \\
\hline & & & & & 1 & 2 & 3 & 4 & 5 \\
\hline Total & $\ldots$ & 96 & & 25 & 19 & 2 & 3 & 0 & 1 \\
\hline $\begin{array}{l}\text { Enzyme positive } \\
\text { Enzyme negative }\end{array}$ & $\begin{array}{l}\cdots \\
\cdots\end{array}$ & $\begin{array}{l}32(33 \%) \\
64\end{array}$ & & $\stackrel{(64 \%)}{9} \%$ & $\begin{array}{r}12 \\
7\end{array}$ & $\begin{array}{l}1 \\
1\end{array}$ & $\begin{array}{l}2 \\
1\end{array}$ & $\begin{array}{l}0 \\
0\end{array}$ & $\begin{array}{l}1 \\
0\end{array}$ \\
\hline
\end{tabular}

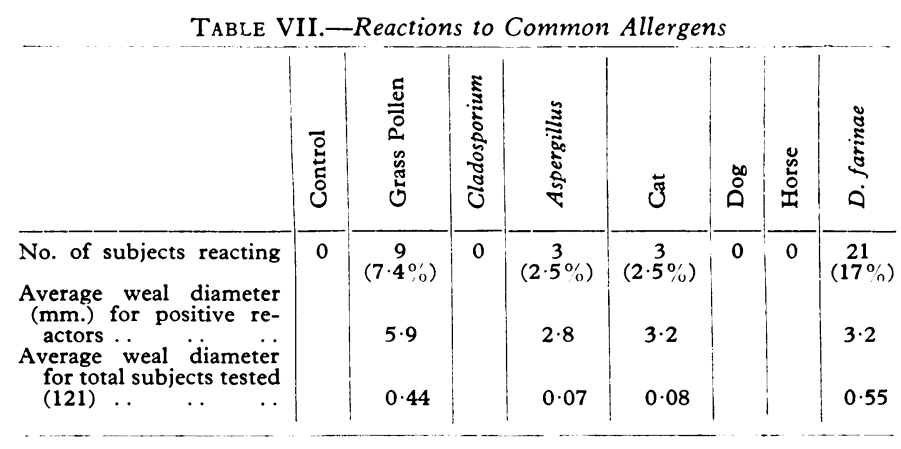

Serological Tests.-Blood samples were requested from those workers who showed positive skin reactions to enzyme extracts; of 43 samples obtained, 25 showed precipitins to the enzyme extracts. The positive sera showed precipitins to all three enzyme preparations.

\section{Discussion}

The results oonfirm the earlier finding that inhalation of dusts containing enzymes derived from $B$. subtilis can produce sensitization, as indicated by positive immediate reactions to skin tests with extracts of these materials. In this study $40 \%$ of the exposed population were found to be sensitized. Moreover, the development of sensitization was significantly affected by the atopic status of the exposed subject. The term "atopic" is used here to describe those subjects who show immediate skin reactions to one or more common allergens on prick testing; multiple reactions indicate a highly atopic subject. The atopic group defined by this criterion is characterized by its tendency readily to develop sensitivity, as shown by skin testing, to environmental materials-for example, house dust-in the course of everyday exposure. The same sensitivity is of ten reflected in the clinical symptoms of the atopic subject-for example, in hay-fever-and the typical "atopic history" includes extrinsic asthma, rhinitis, and infantile (flexural) eczema. The non-atopic majority of the population, in contrast, do not easily become sensitized though they may do so under special conditions of prolonged or intensive exposure, or on contact with a particularly potent allergen (Pepys, 1969). In such circumstances the non-atopic subject develops an isolated sensitivity to a single allergen, in contrast to the multiple sensitization of an atopic subject. The sensitivity of non-atopics may be mediated by reaginic antibody, resembling atopic sensitivity immunologically and clinically, or it may involve other mediators, of which precipitating antibody is now well established. Precipitinmediated reactions may produce a distinct type of asthma, developing some hours after exposure to the allergen, or the alveolar reactions of extrinsic alveolitis. In the present study 25 atopic subjects were identified, and $16(64 \%)$ of them were found to be sensitive to the enzyme extracts. In this respect, those who reacted to a single common allergen and those with multiple reactions to common allergens behaved similarly (Table VI).

What clinical significance may be attached to sensitization to these enzyme dusts? In this survey the history of complaints shows little difference in the sensitized workers compared with non-sensitized workers, except that dyspnoea occurs more often in the sensitized group (Table I) Nevertheless, differences do emerge on analysis of the spirometric measurements, as shown in Tables III and IV and the Chart. Reduced ventilatory capacity is particularly associated with sensitization to $B$. subtilis derivatives : 21 out of $48(44 \%)$ sensitized workers having an F.E.V.I/F.V.C. ratio below $70 \%$ compared with 10 out of $73(14 \%)$ non-sensitized workers. Similarly when mean values are considered, the sensitized group has a mean F.E.V.1 of 2.64 litres and a mean F.E.V.1/F.V.C. ratio of $70 \%$, whereas the non-sensitized group has a mean F.E.V.1 of 3.04 litres and a mean ratio of $79 \%$. The association of reduced ventilatory capacity with atopic status appears to reflect the higher incidence of enzyme sensitization in the atopic group (Table IV).

The contribution of smoking to impairment of ventilatory function is analysed in Table III. This shows that a total of 101 workers were smokers- $84 \%$ of the total group. Of the 48 sensitized workers, 43 were smokers $(90 \%)$ compared with 58

TABLE VIII.-Reactions to Enzyme Extracts

\begin{tabular}{|c|c|c|c|c|c|c|c|c|c|c|c|c|}
\hline & \multicolumn{3}{|c|}{$\begin{array}{l}\text { Alcalase } \\
(\mathrm{mg} . / \mathrm{ml} .)\end{array}$} & \multicolumn{3}{|c|}{$\begin{array}{l}\text { Maxatase } \\
(\mathrm{mg} . / \mathrm{ml} .)\end{array}$} & \multicolumn{3}{|c|}{$\begin{array}{l}\text { Proteinase } \\
\text { (mg./ml.) }\end{array}$} & \multicolumn{3}{|c|}{ Heated Extracts ( $10 \mathrm{mg} . / \mathrm{ml})}$. \\
\hline & 10 & 1 & $0 \cdot 1$ & 10 & 1 & $0 \cdot 1$ & 10 & 1 & 0.1 & Alcalase & Maxatase & Proteinase \\
\hline $\begin{array}{llll}\text { No. of subjects reacting } . . & \ldots & \end{array}$ & $\begin{array}{c}42 \\
(35 \%)\end{array}$ & $\left.\begin{array}{c}31 \\
(26 \%)\end{array}\right)$ & $\begin{array}{c}8 \\
(6.6 \%)\end{array}$ & $\begin{array}{c}36 \\
(30 \%)\end{array}$ & $\begin{array}{c}18 \\
(15 \%)\end{array}$ & $\begin{array}{c}5 \\
(41 \%)\end{array}$ & $\begin{array}{c}42 \\
(35 \%)\end{array}$ & $\begin{array}{c}24 \\
(20 \%)\end{array}$ & $(12 \%)$ & $\begin{array}{c}5 \\
(4 \%)\end{array}$ & $\left(\begin{array}{c}5 \\
(4 \%)\end{array}\right)$ & $\begin{array}{c}5 \\
(4 \%)\end{array}$ \\
\hline $\begin{array}{l}\text { Average weal diameter }(\mathrm{mm} .) \text { for positive } \\
\text { reactors... } \\
\text { Average weal diameter for total subjects } \\
\text { tested }(121) \\
\text {.. }\end{array}$ & 3.8 & $2 \cdot 3$ & $\begin{array}{l}2 \cdot 8 \\
0 \cdot 18\end{array}$ & $3 \cdot 2$ & 2.5 & $\begin{array}{l}2 \\
0.083\end{array}$ & 3.9 & $2 \cdot 6$ & $2 \cdot 3$ & 0.095 & $0 \cdot 116$ & $\begin{array}{l}2 \\
0.083\end{array}$ \\
\hline
\end{tabular}


out of 73 non-sensitized workers $(80 \%)$, and there is also a slightly higher proportion of heavy smokers in the sensitized group. Within both groups the smokers more frequently have an F.E.V.1/F.V.C. ratio below $70 \%$, but in each smoking grade the incidence of reduced ventilatory capacity is higher for the sensitized workers. This confirms the association of sensitization with impairment of ventilatory function and shows that it is not accounted for by the distribution of smoking habits.

These analyses have been made for groups of workers, and it is fully appreciated that for individuals the problem is more oomplex. For example, certain workers whose ventilatory capacity is reduced by these criteria might not appear abnormal on further investigation. Moreover, only one test of respiratory function has been used and workers with normal ventilatory capacity may have other abnormalities-for example, gas transfer impairment.

The results show that the use of the questionary revealed appreciably more information than direct questioning alone. In this survey the administration of the questionary took no more than five minutes, and fitted conveniently into the interval between skin testing and the reading. The importance of the further information obtained in this way is shown in Table IX. This presents information about nine workers with respiratory syndromes, seven of whom, in answer to leading questions, gave no history of respiratory disease. Probably these syndromes antedated enzyme exposure, but this cannot be confirmed in a retrospective survey. Of these nine workers, six show sensitization to the $B$. subtilis derivatives, four having reduced ventilatory capacity; three are unsensitized, of whom one has impaired ventilation.

The original five complainants were included in the survey, and their results are summarized in Table $X$. This shows that four out of the five had evidence of reduced ventilatory capacity and could by no means be said to have recovered. These same four workers were sensitive to the $B$. subtilis derivative on skin testing, and two of them reacted to common allergens. At this stage it is not possible to interpret the precipitin results. Precipitins to $B$. subtilis enzymes have been found in the general population, and it has been suggested that precipitin levels may in fact fall during exposure to high concentrations of the enzymes. The testing of serial serum samples will be necessary to clarify this problem further.

There are inevitably many limitations inherent in a study of this kind carried out in the factory. Spirometric measurements were subject, for example, to the effects of irritant fumes in the atmosphere at certain periods, to the possibility of recent cigarette smoking and to variation in the stage of a work shift at which recordings were made. Similarly, the skin testing may have been affected by residual detergent powder on the forearm, even with prior rinsing. Despite these difficulties we feel that two features stand out in the results of this survey: the higher rate of sensitization to enzyme dusts in atopic subjects, and the reduction of ventilatory capacity associated with sensitization.

Undoubtedly dusts containing derivatives of $B$. subtilis, like many other organic dusts, can produce allergic reactions
TABLE X.-Details of the Five Original Complainants

\begin{tabular}{|c|c|c|c|c|c|}
\hline \multirow{2}{*}{$\begin{array}{l}\text { Survey } \\
\text { No. of } \\
\text { Subject }\end{array}$} & \multirow{2}{*}{$\begin{array}{c}\text { Sputum/ } \\
\text { Chest } \\
\text { Illness } \\
\text { Syndrome }\end{array}$} & \multicolumn{2}{|c|}{ Skin Tests Positive } & \multirow{2}{*}{$\begin{array}{l}\text { Observed } \\
\text { F.E.V., } / \text { F.V.C. }\end{array}$} & \multirow{2}{*}{$\frac{\text { F.E.V. }{ }_{1} \text { (Observed) }}{\text { F.E.V. }{ }_{1} \text { (Expected) }}$} \\
\hline & & $\begin{array}{l}\text { Common } \\
\text { Allergens }\end{array}$ & \begin{tabular}{|l|} 
Enzyme \\
Extracts
\end{tabular} & & \\
\hline $\begin{array}{r}14 \\
71 \\
39 \\
119 \\
75\end{array}$ & $\begin{array}{l} \pm \\
\pm \\
- \\
-\end{array}$ & $\begin{array}{l} \pm \\
\pm \\
-\end{array}$ & $\begin{array}{l}+ \\
+ \\
+ \\
+ \\
-\end{array}$ & $\begin{array}{l}61 \% \\
56 \% \\
67 \% \\
38 \% \\
87 \%\end{array}$ & $\begin{array}{l}72 \% \\
66 \% \\
37 \% \\
53 \% \\
99 \%\end{array}$ \\
\hline
\end{tabular}

affecting the bronchi. In the past less attention was given to this hazard of allergic sensitization than to other effects of inhaled dusts, such as the irritant or fibrogenic effects. It is now clear that industrial environmental control must consider all particles which may enter any part of the respiratory tract and not only those below $7 \mu$ diameter, which have been regarded as "respirable particles."

Where enzyme-containing detergents are manufactured the major effort should be directed to reducing atmospheric levels of dust so far as is possible, with the provision of protective clothing and masks where necessary. Regular medical supervision will then provide a measure of the effectiveness of environmental control. The present survey indicates that appropriate supervision would include a history of respiratory symptoms, spirometry, assessment of atopic status by history and, preferably, skin testing, and skin tests with enzyme extracts, recorded before exposure and at regular follow-up intervals. Indeed the present findings provide a case for identifying atopic subjects at a first assessment and for giving them special consideration. It is hoped that the experience gained in the investigation and control of this particular hazard may be used as a model for the assessment of other organic dusts already encountered or under consideration for industrial use.

\section{Follow-up Report}

The factory was revisited six months later, by which time extensive changes in machinery and production methods had been made. Since the first visit in May $B$. subtilis derivatives had been handled only on six days, the last of which was 11 weeks previously. Eight workers who had been unavailable at the time of the first examination were fully assessed. One worker was found to be an atopic subject with positive skin reactions to the enzyme extracts. He gave a history of asthma and had an F.E.V.1 of 0.68 litre, with an F.E.V.1/F.V.C. ratio of $25 \%$. The seven other workers were non-atopic and did not react to enzyme extracts on skin testing; these workers had normal results on spirometry.

Skin tests with enzyme extracts were repeated on all workers who had negative reactions in May. Of these, one woman had become a positive reactor; she is classified as an atopic subject, having a positive skin reaction to $D$. farinae, and had worked in the factory for a total of six months. Spirometry was repeated on all $\mathbf{4 4}$ workers who had shown enzyme sensitization on skin testing in May. A change of $5 \%$ or more in the ratio F.E.V.1/F.V.C. was regarded as significant. Of 25

TABLE IX.-Details of Workers with Chest Disease Syndromes

\begin{tabular}{|c|c|c|c|c|c|c|c|}
\hline \multirow{2}{*}{$\begin{array}{l}\text { Survey No. } \\
\text { of Subject }\end{array}$} & \multirow{2}{*}{$\begin{array}{c}\text { Chronic } \\
\text { Bronchitis } \\
\text { (Direct } \\
\text { Question) }\end{array}$} & \multirow{2}{*}{$\begin{array}{l}\text { "Chronic } \\
\text { Bronchitis, } \\
\text { Syndrome", } \\
\text { (On Analysis) }\end{array}$} & \multirow{2}{*}{$\begin{array}{l}\text { "Sputum/ } \\
\text { Chest Illness } \\
\text { Syndrome"" } \\
\text { (On Analysis) }\end{array}$} & \multicolumn{2}{|c|}{ Skin Test Results } & \multirow{2}{*}{$\begin{array}{l}\text { F.E.V. } .1 / F . V . C \\
\text { Observed }\end{array}$} & \multirow{2}{*}{$\begin{array}{l}\text { F.E.V. } \text { (Observed) }^{\text {F.E.V.1 }} \text { (Expected) } \\
\text { F.E. }\end{array}$} \\
\hline & & & & Atopy & $\begin{array}{l}\text { B. subtilis } \\
\text { Sensitivity }\end{array}$ & & \\
\hline $\begin{array}{r}5 \\
14 \\
34 \\
105 \\
23 \\
71 \\
64 \\
58 \\
29\end{array}$ & $\begin{array}{l}+ \\
\pm \\
\pm \\
= \\
= \\
= \\
=\end{array}$ & $\begin{array}{l}\overline{-} \\
\pm \\
\pm \\
\pm \\
\overline{-} \\
= \\
-\end{array}$ & $\begin{array}{l}+ \\
+ \\
+ \\
+ \\
+ \\
+ \\
+ \\
+ \\
+\end{array}$ & $\begin{array}{l}\bar{t} \\
\pm \\
\overline{-} \\
\overline{-} \\
\bar{t}\end{array}$ & $\begin{array}{l}+ \\
+ \\
+ \\
\pm \\
+ \\
+ \\
\pm \\
+\end{array}$ & $\begin{array}{l}\mathbf{4 2} \% \\
61 \% \\
65 \% \\
63 \% \\
84 \% \\
56 \% \\
70 \% \\
73 \% \\
86 \%\end{array}$ & $\begin{array}{r}49 \% \\
72 \% \\
67 \% \\
71 \% \\
82 \% \\
66 \% \\
110 \% \\
106 \% \\
110 \%\end{array}$ \\
\hline
\end{tabular}


who had not previously shown impairment of ventilation, 23 were unchanged, but 2 had deteriorated. Of the 19 who did have reduced ventilatory capacity 8 had improved to normal levels, 4 had improved but still had some impairment, 3 were worse, and 4 were unchanged. A further nine workers were retested who were not sensitized but had impaired ventilation in May. Seven had improved, but five of these were still below normal level; the remaining two were worse.

Two points of interest emerged at this stage: (1) the one subject whose skin test reaction to enzyme extracts had converted to positive did so in a period with only six days' exposure to the $B$. subtilis derivative, and (2) in this population the impairment of lung function could be quite severe, and in several cases had not reverted to normal during 11 weeks without contact with $B$. subtilis derivative.
Acknowledgements are due to Dr. T. A. Lloyd Davies, Senior Medical Inspector of Factories, for his guidance and support and for permission to publish; to Professor J. Pepys and the department of clinical immunology, Institute of Diseases of the Chest, for advice, the supply of skin test materials, and serological testing; also to the members of the Factory Inspectorate Medical Branch who helped to carry out the survey (Dr. J. G. S. West, Dr. R. Whitelaw, and Dr. R. Morley).

Requests for reprints should be addressed to Dr. M. Greenberg.

\section{REFERENCES}

College of General Practitioners (1961). British Medical fournal, 2, 973. Flindt, M. L. H. (1969). Lancet, 1, 1177.

Lloyd Davies, T. A. (1970). Report of the Survey of Respiratory Disease in Foundrymen. In press.

Pepys, J. (1969). Hypersensitivity Diseases of the Lungs due to Fungi and Organic Dusts. Basel, Karger.

Pepys, J., Hargreave, F. E., Longbottom, J. L., and Faux, J. (1969). Lancet, 1, 1181

\title{
Method for Measuring Cerebral Dysfunction in Patients with Liver Disease
}

\author{
R. ZEEGEN, ${ }^{*}$ M.B., D.OBST.R.C.O.G.; J. E. DRINKWATER, † B.SC., DIP.PSYCH., A.B.PS.S.; A. M. DAWSON,
}

\begin{abstract}
Cummary: Objective tests of cerebral function were undertaken in 64 outpatients after portal decompression for intrahepatic portal hypertension. These involved scoring the errors in constructing a five-pointed star, and a simple modification of the Reitan trail making test. The first test was found to be less discriminating than the second. There was some correlation between the results and the presence or absence of overt encephalopathy, which-though generally mild-was present in $\mathbf{3 0}$ $(47 \%)$ of the 64 patients.
\end{abstract}

\section{Introduction}

Neuropsychiatric changes may frequently complicate chronic liver disease, especially after portal decompression. Hitherto means of accurate assessment of these changes has been lacking and usually clinical impression has been relied on, when the incidence of portal systemic encephalopathy following portal decompression has been variously estimated as from $13 \%$ (Renwick et al., 1969) to 52\% (Resnick et al., 1969). Grace et al. (1966) calculated a overall incidence of $19 \%$ in 733 patients collected from 13 groups. As mental changes probably occur more often that overt neurological signs, this present study was undertaken, by means of a test designed to demonstrate brain damage, to assess the incidence of cerebral dysfunction in such patients.

This was done, firstly, by devising a scoring system for errors made in drawing a five-pointed star, indicating the constructional apraxia which occurs in hepatic encephalopathy (Davidson and Summerskill, 1956), and, secondly, by applying a modified version of the Reitan trail making test (Reitan, $1955,1958)$. This is a validated test for distinguishing between the presence or absence of organic brain damage; limitations of the test, particularly with psychotic patients, have been fully reviewed (Brown et al., 1958; Goldstein and Neuringer, 1966). The incidence of impaired mental function assessed in these ways could then be compared and contrasted with the incidence of clinically overt encephalopathy.

\footnotetext{
* Research Fellow.

† Principal Psychologist.

$\neq$ Physician.

St. Bartholomew's Hospital, London E.C.1.
}

\section{Patients and Methods}

Control Group.-This comprised 25 patients selected from routine outpatient clinics who could reasonably be assumed to have no organic mental damage and whose clinical examination had disclosed no abnormality. There were 10 men and 15 women in the group, aged from 23 to 73 years. Diagnoses included peptic ulcer, back pain, anxiety state, ulcerative colitis, irritable bowel, and ankle oedema of uncertain aetiology.

Patients.-Sixty-four patients were studied by testing those attending a routine follow-up clinic from March 1968 to October 1969. All had undergone portal decompression for intrahepatic portal hypertension from three months to 19 years previously; this represented a follow-up of over $90 \%$ of the available patients. There were $51(80 \%)$ with hepatic cirrhosis of mixed aetiology, $12(19 \%)$ with "minor" liver changes (Zeegen et al., 1970b), and one with congenital hepatic fibrosis (Kerr et al., 1961). The group comprised 37 men and 27 women aged 14 to 75 years. There was no significant difference in age between the patients and the controls (see Table).

Ages and Incidence of Abnormal Star Error Score and Combined $A$ and $B$ Times of the Reitan Trail Making Test for Control Subjects and Patients

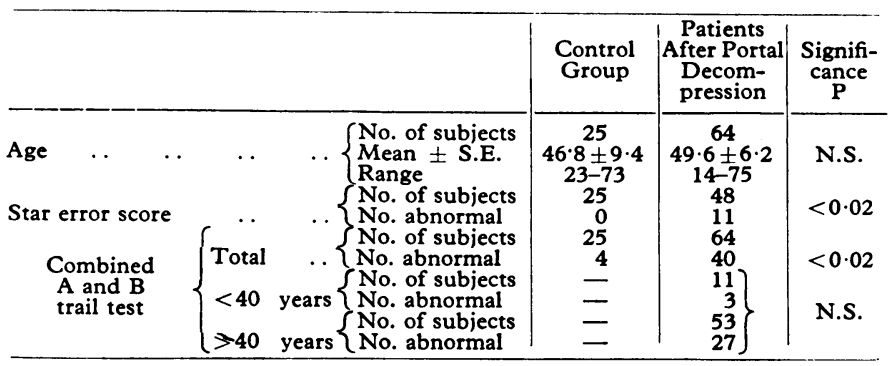

\section{Tests Employed}

Error. Score for Construction of a Five-pointed Star.-Each patient was asked to copy the star accurately. The scoring method was as follows: (A) score one for each sharp star point to a maximum of five, deduct one from the total for each sharp star point in excess of five; (B) score one 